\title{
Heat unit requirement of wheat (Triticum aestivum L.) under different thermal and moisture regimes
}

\author{
HIMANI BISHT, D.K. SINGH, SHALOO, A.K. MISHRA, A. SARANGI, V.K. PRAJAPATI, MAN \\ SINGH and P. KRISHNAN
}

ICAR-Indian Agricultural Research Institute, New Delhi-110012

Email: himanibisht29@gmail.com

\begin{abstract}
An experiment was conducted during 2016-17 and 2017-18 at WTC, ICAR-IARI New Delhi on wheat crop sown on three dates $\left(15^{\text {th }}\right.$ November, $30^{\text {th }}$ November and $15^{\text {th }}$ December $)$ with five irrigation treatments. The results indicated that the number of days required for attaining different phenological stages decreased with delay in sowing.For all the phenological stages, crop sown on $15^{\text {th }}$ November consumed higher heat units and consequently resulted in higher yield and heat use efficiency (HUE) than that of other sowing. However, higher pheno-thermal index (PTI) values were observed for the late sown crop i.e. $15^{\text {th }}$ December. Further, among the irrigation treatments, five irrigations throughout the growing period showed increase in days to physiological maturity as well as heat units and HUE for grain and biological yield as compared to other treatments. Five irrigations throughout the growing period increased the grain yield by 69 per cent and biological yield by 46 per cent that that of one irrigation at CRI stage. However, there was no significant difference observed between four and five irrigations levels. The heat units or GDD had highly significant correlation with biological yield $(r=0.91)$ as well as with the grain yield $(r=0.85)$.
\end{abstract}

Key words: Phenology,growing degree days, pheno-thermal index and heat use efficiency

Wheat (Triticum aestivum L.) is one of the important cereal crops for the majority of world's populations and staple food in India. Wheat being a thermo-sensitive and moisture sensitive crop, the sowing time and irrigation management are two most critical factors that need proper identification for proper crop growth achieving better yield. The crop sown on different sowing dates exposed to a variety of weather conditions during phenological stages affect its growth rate and yield. Temperature is one of the important weather parameters influencing the phenology and yield of wheat crop (Bishnoi et al., 1995).

Similarly, water is another important factor necessary for proper growth, balanced development and higher yield of crop. The terminal heat stress at reproductive stage affects the grain yield of wheat and the water stress accompanied with high temperature at this stage causes drastic reduction in yield (Dar et al. 2018). Because of the very close relation between temperature and plant development various agro-meteorological indices viz. growing degree-days (GDD), photo-thermal index (PTI), heat use efficiency(HUE) etc. are frequently used as indicators for crop development evaluation and was found to be useful as an input in crop growth studies (Rao et al., 1999; Hari
Ram et al. 2012).As irrigation is one of the important factors for proper establishment of wheat and protects the crop from heat stress during reproductive stage, it becomes imperative to generate knowledge of the interactive effect of heat and moisture on growth and yield of wheat. Therefore, keeping this in view, the present study was conducted to determine agrometeorological indices at different phenological stages and to evaluate the correlation between these indices and grain yield.

\section{MATERIALS AND METHODS}

\section{Experimental details}

The wheat cultivar HD-2967 was sown during rabi 2016-17 and 2017-18 in the research farm of Water Technology Centre (WTC) of ICAR-Indian Agricultural Research Institute (IARI), New Delhi, India located at $77^{\circ} 09^{\prime}$ 36 " E longitude and $28^{\circ} 37^{\prime} 55^{\prime \prime} \mathrm{N}$ latitude at an average elevation of $167.17 \mathrm{~m}$ above mean sea level. The experiment was laid out in split plot design with three replications and 15 treatment combinations consisting of 3 dates of sowing and 5 irrigation levels. The main plot comprised 3 dates of sowing $\left(\mathrm{S}_{1}=15^{\text {th }}\right.$ November, $\mathrm{S}_{2}=30^{\text {th }}$ November and $\mathrm{S}_{3}=15^{\text {th }}$ December) while 5 irrigations levels at different stages 
$\left(\mathrm{I}_{1}=\mathrm{CRI}, \mathrm{I}_{2}=\mathrm{CRI}+\right.$ tillering, $\mathrm{I}_{3}=\mathrm{CRI}+$ tillering + jointing, $\mathrm{I}_{4}$ $=\mathrm{CRI}+$ tillering + jointing + anthesis and $\mathrm{I}_{5}=\mathrm{CRI}+$ tillering +jointing +anthesis +dough) were imposed in sub-plots. A recommended common fertilizer dose of 120,60 and $40 \mathrm{~kg}$ $\mathrm{ha}^{-1}$ of N, P and K, respectively was applied during both the experimental years. Full $\mathrm{P}$ and $\mathrm{K}$ and half $\mathrm{N}$ were applied as basal doses and remaining $\mathrm{N}$ dose was top dressed at tillering and booting stages in equal amounts.

Days to different phenological stages were recorded from each sub-plot when approximately 50 per cent of the plants reached that particular stage. After physiological maturity an area of $1 \times 1 \mathrm{~m}^{2}$ from each sub-plot was harvested manually. Biomass yield was determined by taking the weight of above ground plant parts including the grain. After threshing, the grain weight $\left(\mathrm{gm}^{-2}\right)$ was measured and was upscaled to $\mathrm{kg} \mathrm{ha}^{-1}$.

\section{Calculation of agro-meteorological indices}

Meteorological data viz. maximum and minimum temperature, bright sun shine hours and day length during the experiment period was acquired from the agrometeorological observatory located within the IARI farm. The agrometeorological indices such as heat units or growing degree days (GDD), phenol-thermal index (PTI) andheat use efficiency for biological yield $\left(\mathrm{HUE}_{\mathrm{BY}}\right)$ as well as for grain yield $\left(\mathrm{HUE}_{\mathrm{GY}}\right)$ were calculated using following equations:

$\mathrm{GDD}=(\mathrm{Tmax}+\mathrm{Tmin}) / 2-\mathrm{Tb}$

Where,

$\mathrm{T}_{\max }=$ Daily maximum temperature $\left({ }^{\circ} \mathrm{C}\right)$

$\mathrm{T}_{\min }=$ Daily minimum temperature $\left({ }^{\circ} \mathrm{C}\right)$

$\mathrm{T}_{\mathrm{b}}=$ Base temperature $\left(5^{\circ} \mathrm{C}\right.$ used for wheat) (Slafer and Savin, 1991)

$\mathrm{PTI}=\frac{\text { GDD consumed between two phenological stages }}{\text { Number of days taken }}$
$\mathrm{HUE}_{\mathrm{GY}}=\frac{\text { Grain yield }\left(\mathrm{kg} \mathrm{ha}^{-1}\right)}{\text { Accumulated GDD }}$
$\mathrm{HUE}_{\mathrm{BY}}=\frac{\text { Biological yield }}{\text { Accumulated GDD }}$

\section{Statistical analysis}

The data were pooled for two seasons (rabi 2016-17 and 2017-18) and statistically analyzed for different phenological stages, agro-meteorological indices and yield with the help of OPSTAT software (Sheoran et al., 1998) for estimation of analysis of variance (ANOVA) at $p \mathrm{~d}$ " 0.05 probability level.

\section{RESULTS AND DISCUSSION}

\section{Attainment of different phenological stages}

Effect of date of sowing and irrigation levels on number of days to attain different phenological stages shown in Table 1. Sowing dates significantly affected days to attain different phonological stages. The statistical analysis indicated that $15^{\text {th }}$ November sown crop took less days to CRI and tillering as compared to other two sowing dates. This may be due to relatively more temperature experienced at these stages by the $15^{\text {th }}$ November crop as compared to other sowing dates. But after tillering i.e. between jointing to physiological maturity stage, the $15^{\text {th }}$ November sown crop took more days to attain these stages followed by $30^{\text {th }}$ November and $15^{\text {th }}$ December sown crop. The days to physiological maturity were 131 days, 121 days and 111 days for crop sown on $15^{\text {th }}$ November, $30^{\text {th }}$ November and $15^{\text {th }}$ December, respectively. Similar results were reported by Hari Ram et al. (2012) for different variety of wheat in Punjab. Irrigation levels had no effect on days to CRI and tillering. After tillering stage, the least days to jointing, booting, anthesis and physiological maturity were observed for one irrigation (at CRI stage). Whereas the five irrigations supplied during different growth stages $\left(\mathrm{I}_{5}\right)$ showed the longest time to maturity i.e. 125 days as compared to other irrigation treatments. However there was no significant difference between four $\left(\mathrm{I}_{4}\right)$ and five irrigations $\left(\mathrm{I}_{5}\right)$ treatments.

\section{Accumulated heat units}

Accumulated heat units pertaining to different phenological stages of wheat varied with date of sowing and irrigation levels (Table 2). The results indicated that $15^{\text {th }}$ November sown crop availed higher heat units at all the stages and with the successive delay in sowing, heat unit consumption decreased significantly. On average, the $15^{\text {th }}$ November sown crop required the heat units of $262^{\circ} \mathrm{C}$ day for CRI stage, $500^{\circ} \mathrm{C}$ day for tillering stage, $708^{\circ} \mathrm{C}$ day for jointing stage, $795^{\circ} \mathrm{C}$ day for booting stage, $1052^{\circ} \mathrm{C}$ day for anthesis stage, $1190^{\circ} \mathrm{C}$ day for milk stage, $1298^{\circ} \mathrm{C}$ day for dough stage and $1493^{\circ} \mathrm{C}$ day for physiological.Hari Ram et al.(2012) also reported lower consumption of heat units under delayed sowing. Among different irrigation levels, the maximum values of heat units were noticed under full irrigation treatment and with the increase in moisture stress from tillering to dough stage a significant reduction in heat 
Table 1: Effect of date of sowing and irrigation levels on days to attain different phenological stages of wheat (Pooled data of 2016-17 and 2017-18)

\begin{tabular}{|c|c|c|c|c|c|c|c|c|}
\hline Treatment & CRI & Tillering & Jointing & Booting & Anthesis & Milk & Dough & $\begin{array}{l}\text { Physiological } \\
\text { maturity }\end{array}$ \\
\hline \multicolumn{9}{|c|}{ Date of sowing } \\
\hline 15 Nov. & 22 & 48 & 73 & 82 & 104 & 113 & 120 & 131 \\
\hline 30 Nov. & 23 & 50 & 71 & 79 & 101 & 108 & 114 & 121 \\
\hline 15 Dec. & 24 & 51 & 65 & 73 & 90 & 99 & 106 & 111 \\
\hline $\mathrm{CD}$ at $5 \%$ & NS & NS & 0.5 & 0.8 & 1.1 & 0.6 & 0.4 & 1.0 \\
\hline \multicolumn{9}{|c|}{ Irrigation levels } \\
\hline I1 & 23 & 50 & 68 & 75 & 93 & 103 & 110 & 117 \\
\hline $\mathrm{I} 2$ & 23 & 50 & 69 & 76 & 94 & 104 & 113 & 118 \\
\hline $\mathrm{I} 3$ & 23 & 50 & 70 & 78 & 100 & 108 & 112 & 120 \\
\hline I4 & 23 & 49 & 71 & 81 & 102 & 110 & 116 & 124 \\
\hline $\mathrm{I} 5$ & 23 & 50 & 71 & 81 & 102 & 110 & 116 & 125 \\
\hline $\mathrm{CD}$ at $5 \%$ & NS & NS & 0.7 & 1.0 & 1.5 & 0.8 & 0.5 & 1.3 \\
\hline
\end{tabular}

Table 2: Effect of date of sowing and irrigation on accumulated heat units $\left({ }^{\circ} \mathrm{C}\right.$ day) of wheat (Pooled data of 2016-17 and 201718)

\begin{tabular}{|c|c|c|c|c|c|c|c|c|}
\hline Treatment & CRI & Tillering & Jointing & Booting & Anthesis & Milk & Dough & $\begin{array}{l}\text { Physiological } \\
\text { maturity }\end{array}$ \\
\hline
\end{tabular}

\section{Date of sowing}

$\begin{array}{lrrrrrrrr}15 \text { Nov. } & 262 & 500 & 708 & 795 & 1052 & 1190 & 1298 & 1493 \\ 30 \text { Nov. } & 231 & 444 & 643 & 733 & 1047 & 1151 & 1248 & 1394 \\ 15 \text { Dec. } & 205 & 429 & 578 & 687 & 945 & 1101 & 1260 & 1350 \\ \text { CD at } 5 \% & 1 & 5 & 5 & 9 & 15 & 14 & 8 & 18\end{array}$

\section{Irrigation levels}

\begin{tabular}{lrrrrrrrr} 
I1 & 231 & 460 & 625 & 701 & 933 & 1081 & 1204 & 1323 \\
I2 & 232 & 450 & 635 & 715 & 958 & 1093 & 1229 & 1350 \\
I3 & 235 & 460 & 648 & 737 & 1038 & 1164 & 1267 & 1400 \\
I4 & 233 & 459 & 653 & 769 & 1070 & 1200 & 1317 & 1479 \\
I5 & 234 & 459 & 654 & 770 & 1074 & 1199 & 1324 & 1510 \\
CD at 5\% & 1 & 6 & 7 & 12 & 19 & 18 & 10 & 24 \\
\hline
\end{tabular}

units was noticed. At physiological maturity the maximum heat units of $1510{ }^{\circ} \mathrm{C}$ day at were consumed by the crop under five irrigations $\left(\mathrm{I}_{5}\right)$ while the minimum values of 1323 ${ }^{\circ} \mathrm{C}$ day were recorded under one irrigation treatment $\left(\mathrm{I}_{1}\right)$. However, no significant difference in growing degree days was noticed between five and four irrigations treatment as well as between one and two irrigation levels.

However, no significant difference was observed between four and five irrigation treatments. Zhang et al.
(2006) reported that water stress at jointing and anthesis stages reduced the grain yield of wheat by $14-25$ per cent as compared to crops under full irrigation. So, it was observed that increasing irrigation levels $\left(\mathrm{I}_{4}, \mathrm{I}_{5}\right)$ would improve crop growth and thus enable crop to intercept more photosynthetic radiation leading to more biological and grain yield (Ali et al., 2012).

\section{Yield and heat use efficiency (HUE)}

The results indicated that sowing dates and irrigation 
Table 3: Effect of date of sowing and irrigation levels on yield and heat use efficiency (HUE) of wheat (Pooled data of 201617 and 2017-18)

\begin{tabular}{lcccc}
\hline Treatments & $\begin{array}{l}\text { Grain yield } \\
\left(\mathrm{tha}^{1}\right)\end{array}$ & $\begin{array}{l}\text { Biological yield } \\
\left(\mathrm{tha}^{1}\right)\end{array}$ & $\begin{array}{l}\text { HUE on grain yield basis } \\
\left(\mathrm{kg} \mathrm{ha}^{-1}{ }^{\circ} \mathrm{C} \mathrm{day}\right)^{-1}\end{array}$ & $\begin{array}{l}\text { HUE on biological yield } \\
\left(\text { basis kg ha }^{-1}{ }^{\circ} \mathrm{C} \mathrm{day}^{-1}\right)\end{array}$ \\
\hline Date of sowing & 3.2 & 12.3 & 2.2 & 8.2 \\
15 Nov. & 3.1 & 10.9 & 2.1 & 7.8 \\
30 Nov. & 2.4 & 8.1 & 1.7 & 6.0 \\
15 Dec. & 0.2 & 0.5 & 0.1 & 0.5 \\
CD at 5\% & & & & 5.5 \\
Irrigation levels & 1.4 & 7.3 & 1.1 & 6.2 \\
I1 & 1.6 & 8.4 & 1.2 & 7.7 \\
I2 & 2.6 & 10.8 & 1.8 & 8.3 \\
I3 & 4.2 & 12.4 & 2.8 & 8.8 \\
I4 & 4.6 & 13.4 & 3.0 & 0.5 \\
I5 & 0.2 & 0.7 & 0.2 & \\
CD at 5\% & & & & \\
\hline
\end{tabular}

Table 4:Effect of date of sowing and irrigation on pheno-thermal index (PTI) of wheat (Pooled data of 2016-17 and 2017-18)

\begin{tabular}{|c|c|c|c|c|c|c|c|c|}
\hline Treatment & CRI & Tillering & Jointing & Booting & Anthesis & Milk & Dough & $\begin{array}{l}\text { Physiological } \\
\text { maturity }\end{array}$ \\
\hline
\end{tabular}

\section{Date of sowing}

$\begin{array}{lrrrrrrrr}15 \text { Nov. } & 12.0 & 9.0 & 8.0 & 9.6 & 10.0 & 15.0 & 14.8 & 17.2 \\ 30 \text { Nov. } & 9.6 & 8.0 & 9.0 & 10.8 & 14.0 & 15.4 & 17.6 & 20.1 \\ 15 \text { Dec. } & 8.0 & 8.0 & 10.0 & 14.0 & 15.0 & 17.0 & 20.8 & 22.8 \\ \text { CD at } 5 \% & 0.2 & \text { NS } & \text { NS } & 0.4 & 0.4 & 0.7 & 0.6 & 0.5\end{array}$

Irrigation levels

\begin{tabular}{lrrrrrrrrl} 
I1 & 10.0 & 8.3 & 9.0 & 11.0 & 12.7 & 15.0 & 16.7 & 18.7 & \\
I2 & 9.7 & 8.3 & 9.0 & 11.0 & 12.7 & 15.0 & 17.0 & 19.7 \\
I3 & 9.7 & 8.3 & 9.0 & 11.0 & 13.3 & 15.7 & 17.7 & 20.0 \\
I4 & 10.0 & 8.3 & 9.0 & 12.0 & 14.0 & 16.7 & 18.7 & 21.3 \\
I5 & 10.0 & 8.3 & 9.0 & 12.0 & 13.7 & 16.7 & 18.7 & 21.3 \\
CD at 5\% & 0.3 & NS & NS & 0.5 & 0.5 & 0.9 & 0.7 & 0.6 \\
\hline
\end{tabular}

levels significantly affected the grain yield of wheat (Table $3)$. Wheat crop sown on Nov 15 , recorded significantly higher grain and biological yield ever other sowing dates. Five irrigation produced significantly higher yield over other irrigation treatments. The heat use efficiency (HUE) for grain yield and biological yield were computed by using accumulated values of GDD at physiological maturity (Table $3)$. The highest HUE for grain yield $\left(2.1 \mathrm{~kg} \mathrm{ha}^{-10} \mathrm{C}\right.$ days $)$ as well as for biological yield $\left(8.2 \mathrm{~kg} \mathrm{ha}^{-10} \mathrm{C}\right.$ days) recorded under $15^{\text {th }}$ November sown and the minimum values were observed for late sown i.e. $15^{\text {th }}$ December crop. However there was no significant difference observed between $15^{\text {th }}$ November and $30^{\text {th }}$ November sown crop. The higher HUE in $15^{\text {th }}$ November sown crop could be attributed to the proportionate increase in dry matter per each heat unit absorbed. The lower HUE in delayed sowing can be expected due to accumulation of comparable GDD to that of $15^{\text {th }}$ November sowing at later crop growth stages. With respect to irrigations, it was noted that the treatment with five irrigations $\left(\mathrm{I}_{5}\right)$ registered significantly maximum HUE for grain yield $\left(3.0 \mathrm{~kg} \mathrm{ha}^{-10} \mathrm{C}\right.$ days $)$ as well as for biological yield (8.8 $\mathrm{kg} \mathrm{ha}^{-1}{ }^{\circ} \mathrm{C}$ days) followed by four, three, two and one 
Table 5:Pearson correlation between meteorological indices and yield (Pooled data of 2016-17 and 2017-18)

\begin{tabular}{lll}
\hline Agro-meteorological Indices & Biological yield & Grain yield \\
\hline Growing degree days (GDD) & $0.91^{* *}$ & $0.85^{*}$ \\
Pheno-thermal index (PTI) & -0.13 & -0.17 \\
\hline
\end{tabular}

**. Correlation is significant at the 0.01 level (2-tailed). *. Correlation is significant at the 0.05 level (2-tailed).

irrigations treatments. However the values were statistically at par between four and five irrigations treatment. The less heat use efficiency for water stress conditions $\left(\mathrm{I}_{1}, \mathrm{I}_{2}\right.$ and $\left.\mathrm{I}_{3}\right)$ may be ascribed by less yield as well as growing degree days as compared to full irrigation Dar et al., (2018) also reported similar results.

\section{Pheno-thermal index (PTI)}

The pheno-thermal index (PTI) for consecutive phenological stages was also computed and is presented in Table 4. It was observed from Table 5 that after tillering stage the phenol-thermal index gradually increased from jointing to physiological maturity stage in all three dates of sowing and the highest value of PTI was observed at the physiological maturity. Among the sowing dates, the maximum PTI was observed at reproductive stages i.e. at anthesis (15), milking (17), dough (20.8) and physiological maturity (22.8) for $15^{\text {th }}$ December sown crop followed by $30^{\text {th }}$ November and $15^{\text {th }}$ November. This may be due to increase in temperature at reproductive stage reduced the days taken to reach different reproductive stages for $15^{\text {th }}$ December sown crop as compared to $30^{\text {th }}$ November and $15^{\text {th }}$ November sown crops. Gill et al. (2014), Hari Ram et al. (2012) and Dar et al. (2018) also reported that the PTI was affected by the growing environment. Among the irrigation treatments, there was no significant difference in PTI recorded from CRI to jointing stage, but after jointing stage as the number of irrigations increased, it started increasing significantly. However, there was no significant different was observed between value of PTI for four and five irrigations.

Correlation analysis was done between yield (both grain and biological) and meteorological indices (Table 5). Results indicated that GDD was positively correlated with biological as well as grain yield. The GDD showed highly significant relationship with biological yield $(\mathrm{r}=0.91)$ and grain yield (0.85). While PTI showed a negative relationship with both grain yield $(0.13)$ and biological yield $(-0.17)$ but it was not statistically significant. Dar et al. (2018) also reported the positive correlation of GDD with grain yield and biological yield.

\section{CONCLUSIONS}

The crop sown on $15^{\text {th }}$ November took maximum days to attain different phenological stages and required maximum heat units which got reduced with subsequent delay in sowing and the lowest values were noticed for crop sown on $15^{\text {th }}$ December. The $15^{\text {th }}$ November sown crop recorded the highest grain yield and HUE which was statistically at par with $30^{\text {th }}$ November, which suggested that with similar management practices the wheat cultivar HD-2967 can be sown up to $30^{\text {th }}$ November. Among the irrigations, five irrigations treatment took maximumdays to attain physiological maturity and consumed moreheat units or GDD during total crop period resulted in more yield, HUE and PTI as compared to other treatments. However there was no significant difference observed between four and five irrigations. The GDD also showed highly significant positive correlation with grain and biological yield. Therefore, it may be used for forecasting the phenological stages and yield under different sowing date and stage based irrigation scheduling for wheat.

\section{REFERENCES}

Ali, H., Tariq, N., Ahmad, S., Rasheed, M., Chattha, T.H. and Hussain, A. (2012). Growth and radiation use efficiency of wheat as affected by different irrigation levels and phosphorus application methods. J. Anim. Plant Sci., 22(4): 1118-1125.

Bishnoi, O.P., Singh, S. and Niwas, R. (1995). Effect of temperature on phenological development of wheat (Triticum aestivum L.) crop in different row orientation. Indian J.Agric.Sci., 65: 211-214.

Dar, Eajaz Ahmad, Brar, A.S. and Yousuf, A. (2018). Growing degree days and heat use efficiencyof wheat as influenced by thermal and moisture regimes.J. Agrometeorol., 20(2):168-170.

Hari Ram, Singh, G., Mavi, G.S. and Sofia, V.S. (2012). Accumulated heat unit requirement and yield of irrigated wheat (Triticum aestivum L.) varieties under different crop growing environment in central Punjab. $J$. Agrometeorol., 14(2):147-153. 
Gill, K.K., Babuta, R., Kaur, N., Kaur, P. and Sandhu, S.S. (2014). Thermal requirement of wheat crop in different agroclimatic regions of Punjab under climate change scenarios. Mausam, 65 (3): 417-424.

Rao, V.U.M, Singh, D. and Singh, R. (1999). Heat use efficiency of winter crops in Haryana. J. Agrometeorol., 1(2): 143148.

Sheoran, O.P, Tonk, D.S, Kaushik, L.S, Hasija, R.C. and Pannu, R.S. (1998). Statistical software package for agricultural researchworkers. Recent advances in information theory, statistics \& computer applications by D.S. Hooda\& R.C.
Hasija Department ofmathematics statistics, CCS HAU, Hisar(139-143).

Slafer, G.A. and Savin, R. (1991). Development base temperature in different phenological phases of wheat (Triticum aestivum L).J. Exp. Bot., 42: 1077-82.

Zhang, B., Li, F.M., Huang, G., Cheng, Z.Y. and Zhang, Y. (2006).Yield performance of spring wheat improved by regulated deficit irrigation in an arid area. Agric. Water Manage. 79: 28-42.

Received : August 2018 ; Accepted : January 2019 